\title{
Media Competencies for the Citizenship Training of Teachers from Andean America: Colombia and Ecuador
}

\author{
Diana Rivera-Rogel ${ }^{1}$ \\ Universidad Técnica Particular de \\ Loja, Loja, Ecuador
}

\author{
Ligia I. Zuluaga-Arias \\ Nélida María Montoya Ramírez \\ Fundación Universitaria Luis Amigó, \\ Medellin, Colombia
}

\author{
Luis M Romero-Rodríguez \\ Ignacio Aguaded \\ Universidad de Huelva, Huelva, España
}

\begin{abstract}
In an increasingly saturated information and infoxicated world, Media Literacy emerges as a necessity for effective filtering of the vast amount of information we consume. The present research aims to quantitatively analyze the level of media competencies of Colombian (Medellin) and Ecuadorian (Loja and Zamora) teachers by means of the application of an adaptation of the taxonomy from the media competencies model, which consists of 6 dimensions and a total of 12 indicators. The total analyzed sample was comprised of 654 teachers from 81 public and private institutions. A data-gathering instrument was used with the aim of determining their level of media competencies from each of the dimensions. The results showed a low to medium level of media competency knowledge, which illustrated the need for priority interventions based on local, regional and international works, namely those that mobilize scientific, academic and political collaboration to improve the performance of a population that should lead the general training of citizens in media competencies.
\end{abstract}

Keywords: teachers, pedagogy, educational television, communications media, literacy

\section{Docentes e Competência Midiática: Uma Experiência de Cidadania em Colômbia e Equador}

\begin{abstract}
Resumo: Em um mundo cada vez mais saturado e carregado de informações, a competência mediática emerge como uma necessidade de filtragem eficiente da vasta quantidade de informação que consumimos. A presente pesquisa tem como objetivo analisar qualitativamente o grau de competência midiática dos docentes colombianos (cidade de Medellín) e equatorianos (cidades de Loja e Zamora) através da aplicação de uma taxonomia adaptada do modelo de competências mediáticas, que é constituído por seis dimensões e 12 indicadores. A amostra analisada foi composta por 654 docentes de 81 instituições públicas e privadas. Foi aplicado um instrumento de levantamento de dados com a finalidade de determinar o nível de competência midiática dos docentes por cada dimensão. Os resultados obtidos expressam um grau baixo e mediano de competência mediática, o que evidencia a necessidade de intervenções prioritárias a partir de trabalhos locais, regionais e internacionais que mobilizem cooperação científica, acadêmica e política para melhorar o desempeno de um grupo que deveria liderar a formação geral da cidadania.
\end{abstract}

Palavras-chave: professores, pedagogia, televisão educativa, meios de comunicação, alfabetização

\section{Docentes y Competencias Mediáticas: Experiencia de Ciudadanía en Colombia y Ecuador}

\begin{abstract}
Resumen: En un mundo cada vez más sobresaturado de información e infoxicado, las competencias mediáticas emergen como una necesidad para el filtrado efectivo de la ingente cantidad de informaciones que consumimos. La presente investigación tiene como objetivo analizar cuantitativamente el grado de competencias mediáticas de docentes colombianos (ciudad de Medellín) y ecuatorianos (ciudades de Loja y Zamora), a través de la aplicación de una adaptación de la taxonomía del modelo de competencias mediáticas, contentivo de 6 dimensiones y 12 indicadores totales. La muestra total analizada se compuso de 654 docentes de 81 instituciones públicas y privadas, a los que se les aplicó un instrumento de recogida de datos con el fin de determinar su nivel de competencia mediática por cada una de las dimensiones. Los resultados expresan un bajo y mediano nivel de competencias, lo que hace evidente la demanda de intervenciones prioritarias desde trabajos locales, regionales e internacionales que movilicen cooperación científica, académica y política para mejorar el desempeño de una población que debería liderar la formación general de la ciudadanía en competencias mediáticas.
\end{abstract}

Palabras clave: profesores, pedagogía, televisión educativa, medios de comunicación, alfabetización

\footnotetext{
${ }^{1}$ Correspondence Address:

Diana Rivera Rogel. Universidad Técnica Particular de Loja, Dir: San Cayetano,

Código Postal 11-01-608. Loja, Ecuador. E-mail: derivera@utpl.edu.ec
} 
In the current context, it would be difficult to conceive social, cultural and natural transformations of human beings without considering daily interactions with various forms of media. If it is true that these media relationships cannot be avoided, it is also logical to ask the question: Who prepared us for these relationships?

Writing and books as its technological support, as oracles of social interactions between the 19th and the mid20th centuries, found a setting for literacy at schools. Starting with their codes, those who interacted with these tools not only acquired skills for reading, understanding, analyzing and creating, but also acquired a basic training for life (Gutiérrez Martín \& Tyner, 2012).

Notwithstanding, the spaces that should take on educational processes related to audiovisual and digital communication media, so that the population can relate to them more assertively, are becoming blurred. Indeed, this blurring has been true even with the questions that have arisen with the arrival of each of these technologies, related to their expressive, technical, cultural and axiological implications, as well as pleas from international organizations such as United Nations Organization for Education, Science and Culture [UNESCO] $(1970,1982,1987,2011)$ to educate others by establishing critical interactions with these media types. Likewise, addressing a process for which there are neither general agreements, nor nominalizations, nor specific approaches is very complex, as it implies a panorama consisting of various visions and foci (Aguaded Gómez, 2012; Aguaded Gómez \& Cabero Almenara, 1995; Aguaded Gómez \& Romero-Rodríguez, 2015; Aparici Marino, 1996; Bennett, Kendall, \& McDougall, 2011; Buckingham, 2011; Gutiérrez Martín, 2008; Masterman, 1985; Pérez Tornero, 2013; Tyner, 1998, 2010).

The research presented in this article, which is based on the quantitative results of the evaluations in media competencies for both countries, namely for professionals in the fields of obligatory education, not only stems from the Latin American view of education and media. It is also interpreted in conjunction with the Spanish and European experience of addressing media competencies and the conjunction of the media as a subject with that of educational and sociocultural aspects. Specifically, the two studies are adaptations of the technical report from the R\&D project that ended in 2014: "Competencies in audiovisual communication in digital environments: a diagnosis of the needs in three social spheres: communication professionals, professionals from obligatory education, and those from universities". This study counted with participation by the Pompeu Fabra University (UFP), the Universidad of Huelva (UHU) and the Universidad of Valladolid, and is currently being replicated from different perspectives among the universities that comprise the EuroAmerican Inter-University Research Network on Media Competencies for Citizenship, or ALFAMED in Spanish, which has gathered more than 155 researchers from 51 universities and research centers from 13 European and Latin American countries (http://www.redalfamed.org_; consulted: $9^{\text {th }}$ Nov/2015).

In recent years, the arrival of technological advancements, which have provided support for human being's ability of expression, have modified the usual codes used for communication, and have altered the traditional methods of circulating information whilst also generating social and cultural dynamics capable of altering traditional structures (García-Leguizamón, 2010). This situation has always created two key postures: that of expectations and optimistic visions of social progress, and that of confusion: fear, the defining of the risks that come from the use of these artifacts and pleas for attention regarding the need to alphabetize in order to interact with them in a more adequate manner (Montoya Ramírez \& Zuluaga Arias, 2014).

At present, no one can deny that writing, printing and books have been - throughout the history of humanity - the keys to unlocking the past. The Greek philosopher, Plato, in his work titled Phaedrus, presented a "rejection of writing, which he considered to be an inferior form of communication and learning resource compared to what the spoken word could achieve" (García-Leguizamón, 2010, p. 283).

Things have not changed that much since then, but this fear (which was not a fear of the medium itself, but rather a fear that comes from their inappropriate use by certain people who are motivated more by questionable emotions than other motives), taking into account writing and printed media, was joined to the alphabetization that was provided by the school system.

Recalling the historic relationship of tension between society and the media is relevant, as the concerns raised by digital media are not new, but a reiteration of previous issues. And the most worrying fact is based on the conclusion that, if the enquiry and discussion are as old as they are presumed to be, then why have agreements not been reached about how to face them? There are two key causal factors that could explain this: the technological speed that surpasses the processes of appropriation of the media and critical and axiological literacy, and the fact that some social tiers happily conform themselves with instructions on how to use these new artifacts.

In fact, today more than ever we need to decide what the most assertive paths are to take in order to educate citizens about digital media (Romero-Rodríguez \& Aguaded Gómez, 2016). The reasons to do so have always existed, but they have become more acute due to the effect of "infoxication" - or information overload. These factors overwhelm and immobilize the individual's ability to react, provoking an almost blind faith where real questioning is needed (RomeroRodríguez, Gadea, \& Hernández-Díaz, 2016). At the same time, it (infoxication) oversaturates the cognitive abilities of individuals, isolates them from their own affairs, and creates habits of incoherent informative consumption, thus causing their information assimilation capacity to be exceeded (Aguaded Gómez \& Romero-Rodríguez, 2015; Sánchez Carrero \& Contreras Pulido, 2012). For this reason, educating or facilitating media literacy has become imperative.

Traditional media education has gone through four key phases (García-Leguizamón, 2010): protectionism of those who were considered to be the weakest in media knowledge (1960); the reflective critical posture and the active reception 
phases (1960-1970), and the technologist phase, which, until 1980 introduced the media of the time to the classroom, but failed to enquire about its pedagogical and didactic meanings. Today, we talk about the fifth phase, which is more coherent with end of the 20th century and the (present) $21^{\text {st }}$ century, although a defined and cohesive acceptance in terms of its definition is still non-existent (Kendall \& McDougall, 2012).

This fifth phase has received multiple definitions (Gutiérrez Martín \& Tyner, 2012) in different historical periods, with the most common being: "digital literacy" (Gilster, 1997); MIL (Media and Information Literacy) UNESCO (2008); media literacy education, and media competency (Aguaded Gómez, 2012).

Besides these discussions and divergences, there is a general interest in working towards achieving a universal project (Kendall \& McDougall, 2012) of media and information literacy, which generates competencies, whether they are digital, multimodal or media-based. Here "we are referring to a critical, dignifying and freeing literacy, not the training as a user of any new device that emerges" (Gutiérrez Martín \& Tyner, 2012, p. 32).

To this new European and Anglo-Saxon perspective, two Latin American visions can be added. The first is communication and education, which also examines media issues from the point of view of political and cultural processes, and is, according to Huergo (2011), a place "of assembly related to social processes and practices concerning the production of subjects and subjectivities, with social processes and practices of production of senses and meanings, but also a place where equipment and technological and cultural devices in general, are brought together along with subjective dispositions" (Huergo, 2011, p. 20). The second is a concept of competency that, just as the educational sphere, should dissociate itself from the advent of the business world related to the creation of profitability and competitiveness (Martín-Barbero, 2003). For this reason, Martín-Barbero (2003) states that prior to this vision, the notion of competency used to have a more cognitive, linguistic and communicative origin when related to education which should be resuscitated. The first conception of competency in education was associated with the idea of intellectual skill - an ability that was associated with innovation, and therefore, with creativity (Martín-Barbero, 2003). To recover the concept of competency within its cognitive sense, it should be associated with the idea of habitus, such as in the philosophical thought of Bourdieu. This view defines it as cultural competency, which is interesting in educational terms in that it forms part of a system of lasting aptitudes that exist in the subject of learning, within which its experiences, its cultural trajectory, or the ways of acquiring those aptitudes are integrated (Martín-Barbero, 2003).

Estimating levels of competency means recognizing various spheres of development with their respective indicators and environments. In this regard, the research from this article is based on the proposed dimensions and indicators of media competencies by Joan Ferrés and Alejandro Piscitelli. This vision proposes that media competency revolves around six major dimensions: languages, technology, interaction processes, production processes and diffusion, ideology, values, and aesthetics. The taxonomy of the proposed evaluation model is structured around two work environments: the production of one's message and the interaction with foreign messages (Ferrés i Prats \& Piscitelli, 2012). Ferrés i Prats and Piscitelli's proposal is a high value proposal as well, as it can be adapted to other contexts, social and demographic profiles of different populations, such as the studies that are presented here, which were also done for Colombia and Ecuador. This adaptation was necessary because the research is conducted on countries where the developments of media education are very different to European models, and are even different among the geographical settings that are used in this study.

In Colombia, for example, a fledgling process is underway with a platform that is based more on macrodocumentation on the country's education than in specific, systemic actions and reflections with defined environments and actors. The Decennial Plan of Education 2006-2016 (Ministerio de Educación Nacional, 2015) in Colombia officially recognizes "the influence of the media in children's education, especially television, emphasizing the need to assume commitment by the various sectors involved in education and a need to program educational contents responsibly" (Pérez-Rodríguez \& Sandoval, 2013, p. 27). Together with the National Plan for Information and Communication Technologies, it has helped to provide and to maintain a technological infrastructure within the country, which also supports pedagogical processes.

In the same way, the "Curricular Guidelines of the Castilian Language" (Ministerio de Educación Nacional, 2004), visualizes the need to educate students in reading, writing and in the critical analysis of multiple codes, and includes media and communication contents. However, it is more theoretical than real critical-thinking training in as far as media competencies are concerned. As for public organizations, the defunct National Commission of Colombian Television promoted insights and research on this subject matter in 2001, but it was more concentrated on subject areas related to general media education. However, until the present day, there has been little work done to analyze the dissemination and impact of these studies in educational pragmatics in Colombia. The successor of the aforementioned commission, the National Authority on Television, has not yet specified what its contribution to media education will be.

Thus, the academic responsibility of media education has failed to take into account some innovative and passionate teachers, who have worked with media in the teaching learning context (Pérez-Rodríguez \& Sandoval, 2013), and has also failed to recognize independent programs for media education via universities such as "Mirando cómo miramos", (Seeing how we watch), which was developed over a period of six years with the objective of training critical, active and socially responsible television viewers, or those taught by media outlets such as the "School Press", which was designed by producers the written press and utilized to raise students' interest on the logic of this type of media 
and "Educating Whilst Informing", from the newspaper $E l$ Mundo in Medellin.

On its part, Ecuador, in a manner similar to the Colombian experience, has started to implement various initiatives that aim to promote the acquisition of skills related with technologies and the reduction of the digital gap. One key example of this is the Ecuadorian Law of Communication, which states that "the media must produce and disseminate educational contents that promote national production, inclusion, interculturalism, civil participation, diversity, values, national identity, respect and preservation of nature and the promotion of the human rights". In addition, this legal instrument motivates others to promote the exchange of information and knowledge, science and technology, as well as cultural exhibitions and artistic expressions (MarínGutiérrez, Díaz-Pareja, \& Aguaded, 2013, p. 45). On the other hand, the new Organic Law of Communication, directly states the aim of "fostering edu-communication" (Marín-Gutiérrez et al., 2013, p. 45). These restrictive measures give almost clear evidence of the legislative intentions of paradigmatic changes in the inter-relation media-audiences.

In the same way, the educational sector of Ecuador has been gradually equipped with infrastructure, classrooms with computers, computer resources, educational software, training of teaching staff, creation of educational portals and technical support (Marín-Gutiérrez et al., 2013). All of these have enabled students to assimilate the ICTs in a country that was characterized, at the beginning of the millennium, as having a pronounced digital gap caused by economic and geographical reasons, and a lack of know-how. Within this context, the Ministry of Education of Ecuador published a white paper for educational standards with ICTs in 2012, and is pushing for teachers to acquire digital competencies. With this aim in mind, the Ecuadorian Government's Ministry of Education and Culture is now trying to implement, in collaboration with the ESPOL and the Universidad Técnica Particular de Loja (UTPL) the use of ICTs in schools.

The objective of this research was to qualitatively analyze the degree of media literacy of Colombian teachers (Medellín) and Ecuador (cities of Loja and Zamora), through the application of an appropriate taxonomy of media skills model, which was composed of six dimensions and 12 indicators, with the aim to identify this group's abilities, competencies and media literacy tools, as well as their weaknesses, and disabilities that they could have in their habits of media consumption.

\section{Method}

The two studies in this article use as a reference the Spanish R\&D study on enhanced media competencies as briefly described above. However, it should be adapted to the conditions of the school's individual contexts where the processes of media education are still in their budding stages. In light of this scenario, both countries decided to carry out an exploratory approach, namely a descriptive evaluation of the level of media competencies in various social spheres.

\section{Participants}

In Medellin (Colombia), the level of media competency was evaluated for obligatory education teachers, professionals from the field of communication and university teachers in both communication and education areas. In Ecuador, specifically in the cities of Loja and Zamora, the selected communities were comprised by students, professors and parents from public and private educational institutions in both cities. Nevertheless, this research work will only present the quantitative results of the evaluation of media competencies among primary and middle education teachers, thus serving as a joint sample for both exploratory studies. In addition, it would facilitate more equal age range comparisons. This evaluation was carried out with the use of surveys, which used the questionnaires used in Spain as their starting points (Ferrés i Prats \& Piscitelli, 2012).

For both countries, we worked with teachers of students aged between 14 to 18 years old (primary education and middle school education in Colombia and final year of basic general education and the three years of unified general high school in Ecuador). Also, in the city of Medellin-Colombia, the surveyed institutions shared the characteristic of having implemented the strategy "Educating Whilst Informing" from the newspaper El Mundo (Medellin-Colombia), and the "School Press Program" from the newspaper El Colombiano.

In Medellin, 414 surveys of secondary school teachers from 53 Educational Institutions were conducted: $85 \%$ public and $13.8 \%$ private; while in Ecuador, we aimed to obtain a total of 240 surveys in 28 educational institutions in the following order of frequency: private, public and municipal schools. The samples were selected as a function of the researcher's access to the educational institutions, choosing the effective sample by using a simple randomized statistical sampling, where the teachers were randomly chosen per educational center, while always maintaining a correlation with the number of teachers in the different educational stages.

\section{Instruments}

The quantitative studies presented in this manuscript, were explorative-descriptive in scope, combining them to conduct a first analysis, to detect variables, relations and conditions found in the variables to later describe the more important characteristics of a specific object of study (Hernández Sampieri, Fernández Collado, \& Baptista Lucio, 2014), were supported through the application of self-administered questionnaires in the two participating countries: Colombia (Medellín) and Ecuador (Loja and Zamora).

The Colombian questionnaire was structured with 10 socio-demographic questions, four questions about the generalities of media competency level and 25 evaluative questions about the six dimensions of this kind of competency and their respective indicators. On the other hand, the Ecuadorian instrument had seven socio-demographic questions, one question about generalities and 37 evaluative 
questions about the dimensions and indicators.

Most evaluation questions applied in both countries started from close-ended questions with qualitative variables of only one choice: dichotomous (one in the Colombian questionnaire and five in the Ecuadorian) and polytomous (six in Colombian "instrument" and 14 in Ecuadorian); but we also included close-ended questions with multiple choice answers (eight in the Colombian questionnaire and six in the Ecuadorian), Likert scales (Hernández Sampieri et al., 2014) (seven in Colombian "instrument" and 11 in Ecuadorian) and some open-ended questions (three in the Colombian questionnaire).

Likewise, it is made clear that although the questionnaires of the two countries have differences, both agreed to be adaptations of a Spanish research work in media literacy that has already been referenced; considered to have the same dimensions of this competency (Language, Technology, Reception and Interaction, Production and Dissemination, Ideology and Values, and Aesthetics) and the inclusion of questions of knowledge, attitudes and practices; conceptual and methodologically values and validated to ensure their reliability.

\section{Procedure}

Data collection. The greatest demand in light of the application of the evaluation questionnaires was the process of adaptation and the validation of the instrument that guaranteed the methodological rigor in the systematizing and analyzing of the information. This adaptation implied an initial revision of the Spanish instrument and the elaboration of the first questionnaire - both for the Colombian and the Ecuadorian contexts. Once each of these generic instruments was ready, a validation process was performed that requested the implementation of discussion groups with educational experts for each of the subjects from each dimension to adjust the questions to each context. In addition, a pilot study was carried out with 50 mechanisms in order to validate the test's reliability with Cronbach's Alpha coefficient, which provided an Alpha of 885 as a result.

Data analysis. In as far as the coding and the scoring scales for both Colombia and Ecuador - the questions that were to be evaluated in the survey were chosen, as well as the weight of each competency evaluated, and the evaluation of the media competency. For the Colombian case, it should be specified that it was an exploratory study that lacked certain background facts. For this reason, the decision was made to grant the same weight $(16.66 \%)$ to all the dimensions of media competency. Likewise, a scale for the general scoring and according to dimension was specified: high media competency $(80-100 \%)$, with a score of 4.0-5.0; average media competency $(60-79 \%)$, with a score of $3.0-$ 3.9 ; low media competency (40-59\%), with a score of 2.02.9; poor media competency (0-39\%), with a score of 0-1.9. For Ecuador, the scoring of competencies was achieved by asking questions and by determining ratings according to a scale of zero to three, where zero corresponded to low media competency, two to average media competency, and three for the highest level. It is necessary to point out that as this was a quantitative study that was based on variables of qualitative nature- as shown in the works of Ferrés i Prats and Piscitelli (2012), the adaptation of the equal percentages corresponded to 6 dimensions, which were integrally comprised of 12 indicators. These are defined as a complete component, meaning that they are inseparable, indivisible and equal (Ferrés i Prats \& Piscitelli, 2012). Also, the differences between different evaluations/scores used among countries were not in absolute terms because the results of the present research will be shown in terms of percentage of competency and not by natural values $(\mathrm{N})$.

The following results are considered representative for both countries as they included educational information from 654 teachers from 81 public and private institutions from both neighboring countries that share a geographical and social context, and possess a similar development regarding the processes of media education. The group of researchers from both countries carefully selected homogeneous samples that enabled the gathering of coherent evaluative data. These samples responded to non - probabilistic criteria.

\section{Ethical Considerations}

To carry out data collection and data processing, the researchers verified that the participants in the evaluation were fully informed about the evaluation being conducted and were aware of the purpose of the project, who or what group was funding it, how the findings were to be used, if there were any potential adverse impacts of their participation and who would have access to the findings. Also, participants were free to withdraw their participation at any time without negatively impacting their involvement or their relationships with any of the researchers or research bodies involved. The data collection was designed for confidentiality and anonymity, as the participant's identity remained unknown to the research team. Approval by an ethical committee was not needed, as in the countries where the present study took place, this was not a legal requisite, as this field study was non-invasive.

\section{Results}

To contextualize the results, the first thing is to highlight the socio-demographic identifiers of the communities of educators from both Colombia and Ecuador. There were a greater number of surveys carried out by women: $51.4 \%$ (Medellin-Colombia) and $53.7 \%$ in Ecuador, compared with $44.9 \%$ and $46.2 \%$ of men for Colombia (Medellin) and Ecuador, respectively.

However, there were differences on the age data. In Medellin, a significant number of teachers were averageaged adults and above adult age, who were distributed as follows: 40 years old or older (48.53\%); between 26 and 40 years old $(42.98 \%)$ and only $1.69 \%$ were young adults aged between 21 and 25 years old. $6.76 \%$ of respondents did not provide this information. These age ranges were coherent with the teachers' wide experience in the field of education. 
In fact, $51.7 \%$ had between 12 and 19 years of educational experience in this field.

On the other hand in Ecuador, the highest percentage was found to be in the city of Loja: $31 \%$ of educators were in the 22 to 30 age group. In the Ecuadorian city of Zamora, the professors aged 24 to 34 were found in the highest percentage (38\%). These ages also coincided with their educational experience. In Loja, the highest percentage was $49.7 \%$. Here, teachers had had between 1 and 9 years of field experience, whereas in Zamora they had less educational experiencewith $45 \%$ having taught from 0 ( 3 months) to 10 years.

In light of this information, the synthesis of the results from the evaluation of media competencies -namely the dimensions that structure these types of abilities (Ferrés $\mathrm{i}$ Prats \& Piscitelli, 2012) will now be presented.

Based on the Language Dimension, that is, where the knowledge of the various media codes were evaluated as well as the teachers' skills and abilities to use them (i.e. to communicate in a simple, opportune and effective way and interact with them in a critical way), it was observed that in the Colombian city of Medellin, $41 \%$ of teachers obtained a high score in this area, which was comprised of an average of $39 \%, 18 \%$ for low media competency, and $2 \%$ with poor usage. However, the low numerical distance between the high and average score questions the high scores and leads us to think of an estimate nearer to the average, particularly if the other results obtained by educators in connection with this item are to be considered.

In a similar way, in the Ecuadorian cities of Loja and Zamora, media competency was determined, which was represented by the following characteristics: $73.75 \%$ of teachers stated that their interpretation of the language codes in the media and registers was scarce; $60 \%$ did not possess enough capacity to communicate via the media using a different language according to the context, that is, bearing in mind the addressee and the purpose of the message. There was only one high media competency: $66.6 \%$ of the educators were able to interpret and evaluate the various representation codes and the function that they played in a message, using different forms of communication in the educational process.

As for the technological dimension, the trend continued - both for Colombia (Medellin) and for Ecuador (Loja and Zamora), with the results for this competency being average. For this, we evaluated people's knowledge of handling simple technological tools. For the case of Medellin, 54\% of the educators obtained an average score, comprising $16 \%$ and $15 \%$, respectively, for a high score, and $15 \%$ for poor usage. As for the teachers from the cities of Loja and of Zamora, some of the descriptive criteria that resulted from this analysis were: $90 \%$ of the teachers obtained a high evaluation of their capacity to handle the devices and the technological innovations that made multimodal and multimedia communication possible. Between $49 \%$ and $53.5 \%$ of the teachers knew the (internet) browsers well and could use them successfully. However, 62.6 to $70 \%$ of teachers used basic tools for teaching, and only $30 \%$ to $37.4 \%$ used ICTs. Likewise, between 55 and $58.3 \%$ had the least knowledge for manipulating images; between 16 and $21 \%$ did not have the skills necessary to perform this function, and only between 24 and $25.7 \%$ knew and used the tools for this.

With regard to the dimensions Reception and Interaction, how teachers received, assimilates and reflected on communication media were evaluated, and if they were able to exercise their rights and duties concerning the usage and consumption of such media as well. In Medellin, for example, $54 \%$ of the educators had limited skills in this area (shown by a low score of $45 \%$, and a deficient level shown by $9 \%$ ), which was followed by $42 \%$ for average competency, whereas only $4 \%$ of educators obtained a high estimate. In Loja and Zamora, the low level of competency was mostly maintained: 61 to $70 \%$ of the educational staff did not have the ability to search, organize, contrast, prioritize and synthesize information coming from various systems and different environments to generate research methods among their students. Similarly, the low competency was evidenced by 40 and $47 \%$ of educators who did not demonstrate their ability to select, revise and self-evaluate their own media usage. In spite of the existence of average media competencies in the ability to establish relationships with colleagues in digital environments, and that fact that 80.2 to $85 \%$ of respondents demonstrated high media competency when jointly participating in Internet activities, a low score was generally maintained in this area compared with other skills.

As for production and dissemination, the ability of educators to work in the creation of multimedia or multimodal products and their knowledge about the regulation and selfregulation codes that shelter, protect and are demanded from the various social actors in light of our technological world was investigated. $48 \%$ of the teachers from Medellin obtained a low competency score and $12 \%$ had deficient knowledge, while $32 \%$ had a medium level of digital competency, only $8 \%$ had a high level. In Ecuador, low competency was obtained, in spite of the fact that respondents showed a high level of knowledge regarding their rights and the media and the organization to which they should seek to defend such rights (between 60.4 and $72.1 \%$ of teachers). Moreover, between 74.9 and $83 \%$ knew the regulations and selfregulation codes that shelter, protect and are required by the various social actors related to these types of technologies. Among those teachers surveyed in Loja and Zamora, there was limited knowledge about regulation systems and the existence of deontological codes that regulate the work of professionals such as publicists (from 69.5 to $85.6 \%$ did not know these codes existed), and ignored the management of privacy issues in social networks (between 56.6 and $83 \%$ did not know how to manage these privacy functions).

Concerning the level of competitions in the last two dimensions (Ideology and Values and Aesthetics), there were differences in the results from both countries. In MedellinColombia, the estimate was low for both dimensions, while in the two Ecuadorian cities, the scores showed an average competency.

In the dimension Ideology and Values, the ability that educators had to estimate the reliability of the sources of information, and to analyze individual and collective 
identities, as well as to detect media stereotypes and their causes and consequences were all evaluated. In Medellin, $41 \%$ of the educators obtained low competency scores and $17 \%$ had deficient levels of knowledge. Only 37\% reached an average score, whereas $5 \%$ of respondents achieved a high score. In the Ecuadorian cities, the educators obtained an average score of media competency in the identification of sociopolitical messages (from 58.5 to $61.5 \%$ ) and from 30.5 to $37.7 \%$ easily recognized them. Nevertheless, between 63.6 to $64.2 \%$ of teachers demonstrated limited positive relationships with the media, to provide personal autonomy and social transformation. While $30.2 \%$ (in Zamora) and $36 \%$ (in Loja) of teachers did not create messages that avoided prejudices or stereotypes, and between $31 \%$ and $32 \%$ of teachers from both cities did not take these factors into consideration, or rarely referred to them to transmit values.

With regard to aesthetics, a dimension that mainly evaluates mainly the ability of identifying categories such as formal and thematic innovation, originality, style, audiovisual tendencies, as well as whether the media productions are found within an aesthetic framework of good quality or not, it was noted that in Medellin, $54 \%$ of teachers obtained a score between low (36\%) and poor (18\%), whereas $46 \%$ was placed between an average level $(32 \%)$ and a high level (14\%) of media competency. In Ecuador, the result of this dimension was average and was derived from the results that indicated that between 61 and $69.8 \%$ of teachers distinguished certain film tendencies; between 24.5 and $27.8 \%$ did not have a previous education that allowed them to distinguish the tendencies of the film productions; and between 5.7 and $11.2 \%$ did not recognize such elements. Conversely, between $73.6 \%$ and $77.5 \%$ of educators from Zamora and Loja understood the aesthetic characteristics of media content, while 22.5 and $26.4 \%$ of individuals in this group did not recognize this aspect, nor was interested in the aesthetics of media content.

Table 1 presents the level of media competency of colombian and ecuadorian teachers.

Table 1

Evaluation According to Dimension of the Level of Media Competency in Colombian and Ecuadorian Teachers

\begin{tabular}{|c|c|c|c|c|c|}
\hline \multicolumn{5}{|c|}{ Colombia } & \multirow{3}{*}{$\begin{array}{l}\text { Ecuador } \\
\text { the analysis of criteria per } \\
\text { question }\end{array}$} \\
\hline \multicolumn{5}{|c|}{ General Evaluation-percentage } & \\
\hline Dimension & High & Medium & Low & Deficient & \\
\hline 1. Language & $41 \%$ & $39 \%$ & $18 \%$ & $2 \%$ & Medium \\
\hline 2. Technology & $15 \%$ & $54 \%$ & $16 \%$ & $15 \%$ & Medium \\
\hline 3. Reception and Interaction & $4 \%$ & $42 \%$ & $45 \%$ & $9 \%$ & Low \\
\hline 4. Production and dissemination & $8 \%$ & $32 \%$ & $48 \%$ & $12 \%$ & Low \\
\hline 5. Ideology and values & $5 \%$ & $37 \%$ & $41 \%$ & $17 \%$ & Medium \\
\hline 6. Aesthetics & $14 \%$ & $32 \%$ & $36 \%$ & $18 \%$ & Medium \\
\hline
\end{tabular}

Note. As shown, the majority of results are located between medium and low, including the technological dimension.

\section{Discussion}

The results of the evaluation of media competencies conducted in the Colombian city of Medellin and in the Ecuadorian cities of Loja and Zamora validate the initial hypothesis of these studies: consumption of media is not sufficient to possess adequate media literacy, or to be able to demonstrate specific competencies. This situation differs from the reference R\&D study on media competencies "in which a sample of 906 professors, belonging to nine Spanish Autonomous Communities", reached adequate levels of competency, which included a high percentage of the interviewed subjects obtaining high levels (González Fernández, Gozálvez Pérez, \& Ramírez García, 2015, p. 118). Nevertheless, the results are closer to those found for general Spanish population, such as for Andalusia, where people older than 16 years of age had a very low level of media competency $-97.9 \%$ obtained negative scores (Aguaded Gómez et al., 2011).

Similarly, it can be affirmed that the fact of being a young teacher and having less experience (such as the case of the Ecuador), older with more experience (as the Colombian sample) belonging to educational institutions that have had experiences in media such as those of the school press, did not impact this research in a remarkable way, especially in the final evaluation of the media competencies of teachers.

The results from this evaluation of media competency should send off alarm signals in the local, regional and international realm. In the local context, each of the countries should work to achieve a greater political will in political and educational spheres to go beyond consigning legal documents with the "should be" in media education and to implement solid and verifiable media strategies for the long term, and not only single, disjointed actions.

Furthermore, the misbeliefs that the endowment of technological devices and the proper training for their handling are good-enough solutions for media literacy and therefore media competency should be overcome. Although the technological aspect is fundamental, it should be aided by the strengthening of the other dimensions of media 
competency such as interaction with the media, media production, languages, axiology and aesthetics. In addition, as citizens of a globalized world, these low scores of media competency should gather the attention of international organizations that advocate for the improvement of media education, and of countries that lead the in the training processes of media competencies on the real content of media literacy that should be started in the international sphere. As global citizens, it is thus our collective responsibility to join efforts so as to improve literacy and media competency, which are greatly demanded by new interaction environments.

Just as the results from a study by Aguaded Gómez et al. (2011) that was used to generate the methodology presented by Ferrés i Prats and Piscitelli (2012), the lack of teaching experience in the development of media competencies is shown, not only in the teaching plans, but also in the teaching professionals polled. And even with the "Decennial Plan of Education 2006-2016 (Ministerio de Educación Nacional, 2015) in Colombia and the efforts by the Ecuadorian government to recognize the influence of the media in child education (Pérez-Rodríguez \& Sandoval, 2013), the results shown above indicate that the compliance of this pragmatic objective has not been met.

Media illiteracy problems, of social groups such as teachers, who should lead in the general training of the population, should not be added to the social and economic problems that currently exist in countries such as Colombia and Ecuador,. Those individuals who have accepted the social and civil commitment of acting as teachers therefore do not have the excuse: "the teacher that assumes in his speech and practices the model of competency should be competent according to their knowledge. Therefore, based on the above, one cannot execute competencies based on his/ her incompetencies" (Sánchez Carrero \& Aguaded Gómez, 2013, p. 2).

This exploratory-descriptive analysis has allowed us to understand and specify the existing deficiencies of this subject matter in obligatory secondary education in Medellín (Colombia) and Loja and Zamora (Ecuador). By recognizing said weaknesses, it is easier to understand and pose proposals for improvement. The delving into the media competency deficiencies should be the object of more indepth study (mixed methods), with the goal of understanding the limitations of access and media consumption of teachers and students. In this way, it could be argued for the need for a periodical evaluation of the level of media competency of the subjects of this study, as an incentive to bolster abilities and competencies.

\section{References}

Aguaded Gómez, J. I. (2012). La competencia mediática, una acción educativa inaplazable [Media proficiency, an educational initiative that cannot wait]. Comunicar, 20(39), 7-8. doi:10.3916/C39-2012- 01-01
Aguaded Gómez, J. I., \& Cabero Almenara, J. (1995). Educación y medios de comunicación en el contexto iberoamericano [Education and educational facilities in the Ibero-American context]. Sevilla, España: Universidad Internacional de Andalucía. Retrieved from http://dspace. unia.es/bitstream/handle/10334/1512/02AguadedCabero. pdf? sequence $=2$

Aguaded Gómez, J. I., Ferrés i Prats, J., Cruz Díaz, M. R., Pérez Rodríguez, M. A., Sánchez Carrero, J., \& Águeda Delgado, L. (2011). El grado de competencia mediática en la ciudadanía andaluza [The level of media proficiency in the Andalucian citizenship]. Huelva, España: Grupo Comunicar. Retrieved from http://rabida.uhu.es/dspace/ bitstream/handle/10272/6892/Grado_de_competencia mediatica.pdf? sequence $=2$

Aguaded Gómez, J. I., \& Romero-Rodríguez, L. M. (2015). Mediamorfosis y desinformación en la infoesfera: Alfabetización mediática, digital e informacional ante los cambios de hábitos de consumo informativo [Mediamorphosis and misinformation in the infosphere: Media, digital and information literacy face of changes in information consumption habits]. Education in the Knowledge Society, 16(1), 44-57. doi:10.14201/ eks20151614457

Aparici Marino, R. (1996). La revolución de los medios audiovisuales: Educación y nuevas tecnologías [The revolution of audiovisual means: Education and new technologies]. Madrid, España: Ediciones de la Torre.

Bennett, P., Kendall, A., \& McDougall, J. (2011). After the media: Culture and identity in the 21st century. London, United Kingdom: Routledge.

Buckingham, D. (2011). Media literacy: New directions or losing our way? Manifesto for Media Education Symposium. London, United Kingdom: Royal Institute of British Architects.

Ferrés i Prats, J., \& Piscitelli, A. (2012). La competencia mediática: Propuesta articulada de dimensiones e indicadores [Media competency. Articulated proposal of dimensions and indicators]. Comunicar, 19(38), 75-82. doi:10.3916/C38-2012-02-08

García-Leguizamón, F. (2010). Educación en medios ayer y hoy: Tópicos, enfoques y horizontes [Media education through history: Topics, approaches and horizons]. Magis, 2(4), 279-298. Retrieved from http://www.redalyc.org/ pdf/2810/281021692003.pdf

Gilster, P. (1997). Digital literacy. New York, NY: Wiley \& Sons.

Gutiérrez Martín, A. (2008). Educar para los medios en la era digital [Media education in the digital age]. Comunicar, 16(31), 451-456. doi:10.3916/c31-2008-03-034

Gutiérrez Martín, A., \& Tyner, K. (2012). Educación para los medios, alfabetización mediática y competencia digital [Media Education, Media Literacy and Digital Competency]. Comunicar, 19(38), 31-39. doi:10.3916/ C38-2012-02-03 
González Fernández, N., Gozálvez Pérez, V., \& Ramírez García, A. (2015). La competencia mediática en el profesorado no universitario. Diagnóstico y propuestas formativas [The media competency in the non-university teachers. Diagnostic and training proposals]. Revista de Educación, (367), 117-146. doi:10.4438/1988-592XRE-2015-367-284

Hernández Sampieri, R., Fernández Collado, C., \& Baptista Lucio, M. P. (2014). Metodología de la investigación [Investigation methodology] (6a ed.). México, DF: McGraw-Hill.

Huergo, J. (2011). Sentidos estratégicos de comunicación/ educación en tiempos de restitución del Estado. In E. Da Porta (Comp.), Comunicación y educación: Debates actuales desde un campo estratégico [Ongoing debates from a strategic field] (pp. 15-39). Córdoba, Argentina: Gráfica del Sur.

Kendall, A., \& McDougall, J. (2012). Alfabetización mediática crítica en la postmodernidad [Critical media literacy after the media]. Comunicar, 19(38), 21-29. doi:10.3916/C38-2012-02-02

Masterman, L. (1985). Teaching the media. London, United Kingdom: Comedia.

Martín-Barbero, J. (2003). Saberes hoy: Diseminaciones, competencias y transversalidades [Knowledge today: Dissemination, competencies and transversalities]. Revista Iberoamericana de Educación, (32), 17-34. Retrieved from http://rieoei.org/rie32a01.htm

Marín-Gutiérrez, I., Díaz-Pareja, E., \& Aguaded, I. (2013). La competencia mediática en niños y jóvenes: La visión de España y Ecuador [The media competency in children and teenagers]. Chasqui, (124), 41-47. doi:10.16921/ chasqui.v0i124.17

Ministerio de Educación Nacional. (2004). Serie lineamientos curriculares: Lengua castellana [Serie curriculum guidelines: Spanish] Retrieved from http:// www.mineducacion.gov.co/1621/articles-339975_ recurso_6.pdf

Ministerio de Educación Nacional. (2015). Plan Decenal de Educación 2006-2016: Pacto social por la educación [Social pact for education]. Retrieved from www.oei.es/ pdfs/pde.pdf

Montoya Ramírez, N. M., \& Zuluaga Arias, L. I. (2014). Educar mientras se informa: Una propuesta de resignificación de la prensa tradicional [Educating while reporting: A proposal for a redefinition of traditional press]. Signo y Pensamiento, 33(64), 30-44. doi:10.11144/Javeriana.SyP33-64.emsi

Pérez-Rodríguez, M. A., \& Sandoval, Y. (2013). Avances para el desarrollo de la competencia mediática a partir del currículum de primaria en Colombia y España [Advances in the development of media competency from the curriculum of primary in Colombia and Spain]. Chasqui, (124), 26-33. doi:10.16921/chasqui. v0i124.15
Pérez Tornero, J. M. (2013). Midiendo la alfabetización mediática en Europa 2005-2010. [Measuring the media literacy in Europe 2005-2010]. Barcelona, España: Universitat Autònoma. Retrieved from http:// www.mediamilion.com/wp-content/uploads/2013/10/ Yearbook-2005-2010.pdf

Romero-Rodríguez, L., \& Aguaded Gómez, J. I. (2016). Consumo informativo y competencias digitales de estudiantes de periodismo de Colombia, Perú y Venezuela. [Consumption of information and digital competencies of journalism students from Colombia, Peru and Venezuela]. Convergencia Revista de Ciencias Sociales, 23(70), 3557. Retrieved from http://convergencia.uaemex.mx/ article/view/3806/2618

Romero-Rodríguez, L. M., Gadea, W. F., \& Hernández-Díaz, G. (2016). Incidencia de la diversificación del ecosistema comunicativo en la sobresaturación informativa [Incidence of diversification of communication ecosystem in the information oversaturation]. Comunicación. Estudios Venezolanos de la Comunicación, (171-172), 25-33. Retrieved from https://goo.gl/vuZQZH

Sánchez Carrero, J., \& Aguaded Gómez, J. I. (2013). El grado de competencia mediática en la ciudadanía andaluza [The level of media proficiency in the Andalucian citizenship]. Estudios sobre el Mensaje Periodístico, 19(1), 265-280. doi:10.5209/rev_ESMP.2013.v19.n1.42521

Sánchez Carrero, J., \& Contreras Pulido, P. (2012). La competencia mediática en Andalucía: Un camino por recorrer [The media competition in Andalusia: A way to go]. Mediaciones Sociales, (11), 23-44. doi:10.5209/rev MESO.2012.v11.41268

Tyner, K. (1998). Literacy in a digital world: Teaching and learning in the age of information. Mahwah, NJ: Lawrence Erlbaum.

Tyner, K. (2010). Media literacy. New agendas in communication. New York, NY: Routledge.

United Nations Organization for Education, Science and Culture. (1970). La alfabetización funcional: Cómo y por qué [The functional literacy: How and why]. Paris, France: UNESCO. Retrieved from http://unesdoc.unesco. org/images/0013/001326/132679So.pdf

United Nations Organization for Education, Science and Culture. (1982). Declaración de Grünwald. Retrieved from http://www.mediamilion.com/wp-content/ uploads/2011/05/Declaraci\%C3\%B3n-de-Grunwald.pdf

United Nations Organization for Education, Science and Culture. (1987). Revised recommendations concerning the international standardization of educational statistics (UNESCO's Standard-setting Instruments, V3 B4). Paris, France: UNESCO.

United Nations Organization for Education, Science and Culture. (2011). Paris declaration on media and information literacy in the digital era. Retrieved from http://goo.gl/DkGtWF 
United Nations Organization for Education, Science and Culture. (2008). Teacher training curricula for media and information literacy. Report of the International Expert Group Meeting. Paris, France: UNESCO. Retrieved from http://www.unesco.org/new/fileadmin/MULTIMEDIA/ $\mathrm{HQ} / \mathrm{CI} / \mathrm{CI} / \mathrm{pdf} /$ teacher_training_curricula_mil_meeting june_2008_report_en.pdf

Diana Rivera-Rogel is Full-time Professor at the Universidad Técnica Particular de Loja.

Ligia I. Zuluaga Arias is Full-time Professor at the Fundación Universitaria Luis Amigo.

Nélida María Montoya Ramírez is Full-time Professor at the Faculty of Social Communication and Advertising of Fundación Universitaria Luis Amigo.

Luis M. Romero-Rodriguez is Visiting Professor at the University of Huelva and International University of Andalusia.

Ignacio Aguaded is Full-time Professor at the University of Huelva.

Received: Jan. 15, 2016

1st Revision: May 17, 2016

Approved: May 17, 2016

How to cite this article:

Rivera-Rogel, D., Zuluaga-Arias, L. I., Montoya Ramirez, N. M., Romero-Rodriguez, L. M., \& Aguaded, I. (2017). Media competencies for the citizenship training of teachers from Andean America: Colombia and Ecuador. Paidéia (Ribeirão Preto), 27(66), 80-89. doi:10.1590/198243272766201710 